Jurnal Syntax Imperatif: Jurnal Ilmu Sosial dan Pendidikan

p-ISSN: 2721-2491 e-ISSN: 2721-2246

Vol. 1, No. 3, Juli 2020

\title{
Implementasi Kebijakan Bos dalam Meningkatkan Kinerja Guru di SDN Babakan Kadu Kota Tasikmalaya
}

\section{Yudha Sanjaya Surya Nugraha}

Sekolah Tinggi Ilmu Administrasi Negara (STIAN) YPPT Priatim Tasikmalaya, Indonesia

E-mail: yudha.nazriel@gmail.com

\begin{abstract}
Abstrak
Penelitian ini bertujuan untuk mengetahui dan menganalisa pengaruh Implementasi Kebijakan Bantuan Operasional Sekolah (BOS) berkenaan dengan peningkatan Kinerja Guru di Sekolah Dasar Negeri Babakankadu di Kota Tasikmalaya. Metode penelitian yang digunakan adalah Studi Kasus dengan metode penelitian Kualitatif karena penelitian ini melihat dan mendiskripsikan situasi sosial berupa implementasi kebijakan dana BOS di SD N Babakankadu Kota Tasikmalaya, memahami arti setiap peristiwa yang berkaitan dengan pelaksanaan kebijakan beserta kendala dan cara mengatasinya. Hasil penelitian menunjukan bahwa Implementasi Kebijakan Bantuan Operasional Sekolah (BOS) berkenaan dengan peningkatan Kinerja Guru di SD Negeri Babakankadu di Kota Tasikmalaya, memberi pengaruh secara positif dan signifikan terhadap peningkatan kinerja guru.
\end{abstract}

Kata kunci: Bantuan Operasional Sekolah; Kinerja Guru; Implementasi Kebijakan;

\section{Pendahuluan}

Pendidikan adalah proses ketika seseorang mengembangkan kemampuan, sikap dan bentuk-bentuk tingkah laku lainnya di dalam masyarakat tempat dia hidup, proses sosial ketika orang dihadapkan pada pengaruh lingkungan (terutama yang berasal dari sekolah) sehingga ia dapat memperoleh perkembangan sosial dan kemampuan pribadi yang terbaik (Dictionary of Education).

Dunia pendidikan selalu penuh dinamis dan harus terus beradaptasi, seolah-olah tidak mundur dari berbagai masalah, dan selalu berkembang mengikuti perubahan dan perkembangan yang begitu cepat. Bukan hanya masalah substantif pendidikan itu sendiri, tetapi juga sarana, fasilitas, dan proses pembelajaran yang efektif dan efisien agar mencapai tujuan.

Dunia pendidikan selalu dinamis dan akomodatif seakan tak surut dari berbagai persoalan, selalu berkembang mengikuti perubahan dan perkembangan yang begitu cepat. Bukan hanya persoalan esensi dari pendidikan itu sendiri tetapi juga menyangkut sarana, fasilitas dan juga proses pembelajaran yang efektif dan efisien dan diupayakan tepat kearah tujuan yang ingin dicapai.

Dalam beberapa dekade terakhir, dengan dukungan bantuan internasional, beberapa negara berkembang telah melakukan upaya besar untuk menyekolahkan anakanak usia sekolah agar mencapai pendidikan, terutama pencapaian pendidikan dasar yang dianggap meningkatkan standar hidup negara-negara berkembang dan mempercepat pertumbuhan ekonomi negara. 
Menurut analisis para pakar dan praktisi pendidikan di Indonesia, saat ini setidaknya ada enam isu utama yang memerlukan pertimbangan latar belakang di bidang terkait, yaitu kualitas pendidikan, efisiensi, manajemen, pemerataan, partisipasi masyarakat, dan akuntabilitas pendidikan.

Layak untuk dikaji lebih lanjut bahwa lembaga penelitian SMERU (2005) bekerja sama dengan Bank Dunia untuk menentukan hasil studi tentang kinerja siswa sekolah dasar Indonesia: peran guru dan sekolah. Hasil penelitian mencakup berbagai variabel yang mempengaruhi kinerja siswa, yaitu variabel guru (ketidakhadiran guru, pengalaman guru, pekerjaan guru di luar sekolah dan proporsi guru perempuan), kondisi dan karakteristik sekolah (bahasa pengantar sekolah, ukuran kelas, rasio guru dan siswa, Jarak sekolah, fasilitas sekolah), manajemen sekolah dan alokasi keuangan.

Oleh karena itu, faktor kinerja guru adalah salah satu indikator penting untuk meningkatkan kinerja / prestasi siswa. Meskipun penelitian lebih lanjut diperlukan untuk memahami kebutuhan sekolah atau skala biaya operasional, untuk meminta peran orang tua siswa dalam situasi ini, itu tidak hanya dapat mendukung keberlanjutan operasi sekolah, tetapi juga membantu siswa berhasil dalam belajar dan dengan demikian meningkatkan pembelajaran.

Dengan demikian, faktor kinerja guru merupakan salah satu indikator penting bagi peningkatan kinerja/prestasi murid/siswa. Walaupun masih perlu dilakukan penelitian lebih jauh besarnya kebutuhan atau biaya operasional sekolah sehingga peranan orang tua siswa dalam hal ini diperlukan baik sebagai penopang keberlangsungan operasional sekolah maupun dalam keberhasilan dalam proses pembelajaran siswa dalam peningkatan prestasi belajarnya (Putri, 2019).

\section{Metode Penelitian}

Penulis menggunakan metode penelitian deskriptif dengan pendekatan kualitatif. Objek penelitian ini adalah guru-guru SDN Babakankadu, dan seluruh warga SDN Babakankadu yang terkait dengan penelitian ini.

Teknik pengumpulan data dilengkapi melalui observasi dan wawancara. Dan teknik analisis data ini dilengkapi dengan reduksi data, tampilan data, dan kesimpulan serta verifikasi untuk mengetahui apa yang menyebabkan dampak implementasi kebijakan dana bantuan operasional sekolah terhadap peningkatan kinerja guru di Sekolah Dasar Babakankadu di Kota Tasikmalaya.

\section{Hasil dan Pembahasan}

Secara keseluruhan, sosialisasi penggunaan dana BOS yang dilakukan oleh Dinas Pendidikan Kota Tasikmalaya mengalami kemajuan dengan lancar, yaitu diadakan setidaknya setahun sekali, semua kepala sekolah dan direktur keuangan BOS dari masing-masing sekolah berpartisipasi. Sosialisasi membahas pedoman teknis BOS lebih menekankan pada anak-anak, tetapi tidak ada pembahasan khusus dari Dinas Pendidikan tentang penggunaan dana BOS untuk pengembangan guru. 
Penggunaan dana BOS untuk pengembangan guru juga tidak ada presentase minimum dan maksimal yang di atur oleh Juknis BOS selama pihak sekolah setuju untuk melaksanakan kegiatan hal itu tidak jadi masalah.

Dana BOS digunakan untuk mengembangkan kemampuan guru, antara lain digunakan untuk melakukan kegiatan tertentu yang berkaitan dengan pengembangan guru, seperti MGMP atau konsultasi guru mata pelajaran. Kegiatan ini adalah forum untuk guru dengan mata pelajaran yang sama untuk bertukar pikiran dan profesionalisme guru dalam pembelajaran dan evaluasi peserta didik. Siswa yang berdampak pada kualitas pendidikan sekolah. Kedua, sekolah juga melakukan kegiatan pelatihan atau seminar.

Sekolah mengadakan kegiatan pelatihan IT dan pelatian $e$-learning yang kedua hal tersebut dapat menambah wawasan guru yang akan meningkatkan mutu guru di sekolah. pelatihan IT guru-guru diberikan pelatihan bagaimana menggunakan teknologi dalam melakuan kegiatan belajar mengajar, mengolah nilai serta mengevaluasi peserta didik dan manfaat yang di dapatkan oleh guru adalah guru tidak jadi gaptek dalam menggunakan teknologi dan pelatihan e-learning adalah wadah baru yang digunakan untuk mempermudah dalam mengajar dan menyampaikan materi serta guru bisa melakukan ujian harian dan tryout secara online.

Kegiatan pelatihan yang sering dilakukan dengan memakai dana BOS adalah kegiatan pelatihan e-learning. Selain itu pihak sekolah juga bisa menggunakan dana BOS untuk kegiatan yang tidak terkait dengan keilmuan seperti kegiatan jasmani dan rohani. Kegiatan tersebut dapat dimasukan ke dalam komponen pengembangan guru, tenaga kependidikan dan pengembangan manajemen sekolah. Sedangkan sekolah yang tidak memakai dana BOS untuk pengembangan guru mengatakan bahwa prioritas utama dari dana BOS ini adalah untuk peserta didik jadi untuk pengembangan guru sekolah hanya mengikuti kegiatan bedah SKL atau standar kompetensi lulusan yang dimana kegiatan tersebut adalah kegiatan yang diadakan pemerintah kota dalam meningkatkan komptensi lulusan sekolah.

Selain untuk biaya peningkatan kompetensi guru, Pemeritah saat ini memberikan kebijakan bahwa dana BOSdapat digunakan untuk membayar honorarium tenaga honorer. Sehingga dari segi honor pun, guru merasakan dampak yang lebih baik. Entah itu dengan peningkatan jumlah nominal pendapatan, atau kenaikan. Secara psikologis, hal tersebut akan memberikan dampak berupa semangat untuk melaksanakan pembelajaran yang lebih baik lagi.

Berdasarkan penelitian yang dilakukan di SDN Babakankadu Kota Tasikmalaya, dengan adanya dana BOS yang dialokasikan untuk peningkatan skill atau kemampuan guru, baik dari segi akademik maupun dalam bidang IT, sehingga memudahkan dan sedikit meringankan tugas guru. Hal tersebut berdampak pada peningkatan kinerja guru yang lebih efektif dalam memberikan pelajaran kepada siswa, sehingga jika hal tersebut dilakukan secara kontinyu, maka standar kompetensi lulusan pun atau prestasi siswa pun akan meningkat. Sehingga ketika guru menjadi kompeten, maka kinerja guru 
Yudha Sanjaya Surya Nugraha

tersebut akan meningkat, prestasi belajar siswa juga meningkat, sehingga mutu pendidikan secara global pun ikut meningkat. ("Tentang BOS: penggunaan dana BOS SD Kota Tasikmalaya.," n.d.)

\section{Kesimpulan}

Dari hasil pengamatan dan wawancara dengan para pemangku kepentingan dan warga sekolah terkait dengan kebijakan tersebut telah menghasilkan penelitian tentang implementasi Kebijakan Dana Bantuan Operasional Sekolah SDN Babakankadu di Kota Tashikmalaya. Implementasi kebijakan pendanaan bantuan operasi sekolah SDN Babakankadu di Tasikmalaya memiliki makna positif dan signifikan untuk meningkatkan kinerja guru, dan diketahui bahwa hal itu juga memiliki dampak positif pada prestasi siswa. 


\section{BIBLIOGRAFI}

Hadiyanto, N. (2017). Pengaruh Implementasi Kebijakan Pemberian Bantuan

Operasional Sekolah (Bos) Terhadap Peningkatan Kinerja Guru Dan Partisipasi

Orang Tua Siswa Dalam Peningkatan Prestasi Belajar Siswa Pada Sekolah

Menengah Pertama Negeri di Kabupaten Garut. Jurnal Pendidikan UNIGA, 9(1), $103-116$.

Putri, A. S. (2019). Kebijakan Publik: Pengertian, Tujuan dan Ciri-ciri.

Tentang BOS: penggunaan dana BOS SD Kota Tasikmalaya. (n.d.).

https://www.kompas.com/skola/read/2020/02/06/210000269/kebijakan-publik--pengertiantujuan-dan-ciri-ciri?page=all. 